\title{
LAYANAN BELAJAR ANAK ANAK BERKEBUTUHAN KHUSUS DI GEREJA SERPONG TANGERANG
}

\author{
M Kusuma Wardhani
}

Fakultas Ilmu Pendidikan Universitas Pelita Harapan

\author{
Abstrak \\ Kusuma Wardhani \\ kusuma.wardhani@uph.edu
}

\begin{abstract}
Universitas Pelita Harapan (UPH) sebagai institusi pendidikan Kristen mempunyai visi misi yang holistik. Tidak hanya menekankan sisi akademis tetapi juga membangun karakter dan spiritual para mahasiswanya. Dari visi misi tersebut, UPH menetapkan beberapa goal, dimana salah satu nya adalah mewujudkan pengabdian masyarakat sebagai tanggung jawab untuk turut serta dalam pembangunan Negara Indonesia, lewat pembangunan masyarakat. Mahasiswa Fakultas Pendidikan UPH mempunyai peran yang signifikan dalam membangun masyarakat lewat program pengabdian kepada masyarakat. Program Layanan Pembelajaran yang dilakukan sebagai bentuk pengabdian masyarakat, tidak hanya mencakup pada pendidikan formal saja seperti persekolahan, tetapi juga pada pendidikan non formal seperti bimbingan belajar. Sedangkan targetnya tidak hanya untuk anak anak normal, tetapi juga untuk anak anak berkebutuhan khusus. Adapun tujuan dari layanan belajar ini adalah untuk 1) mendukung orang tua dari anak anak yang berkebutuhan khusus, supaya tetap bersemangat dan mempunyai pengharapan dalam mengasuh dan membesarkan anak anak nya, dengan mengikuti kebaktian khusus untuk orangtua anak anak spesial 2) menyediakan layanan belajar bagi anak-anak berkebutuhan khusus. Metode yang dipakai adalah pengajaran Firman Tuhan dan pemberian aktivitas belajar bagi anak-anak yang terlibat dalam program. Hasilnya, kegiatan mendapatkan sambutan yang sangat baik dari para orang tua, sehingga akan dilanjutkan pada semester berikutnya dengan mempertimbangkan beberapa evaluasi.
\end{abstract}

Kata kunci : pengabdian masyarakat, anak berkebutuhan khusus, layanan belajar.

\section{PENDAHULUAN}

Universitas Pelita Harapan sebagai institusi pendidikan Kristen mempunyai visi misi yang holistik. Tidak hanya menekankan sisi akademis tetapi juga membangun karakter dan spiritual para mahasiswanya. Dari visi misi tersebut, UPH menetapkan beberapa goal nya, dimana salah satu nya adalah mewujudkan pengabdian masyarakat sebagai tanggung jawab untuk turut serta dalam pembangunan Negara Indonesia lewat pembangunan masyarakat.

Melalui visi misi dan tujuannya UPH dalam situs http://www.ac.id/id tentang identitas-uph/visi-danmisi, mengharapkan para lulusan nya akan mempunyai kompetensi yang secara kritis, menyeluruh dan bermoral dalam merespons setiap tantangan yang dihadapi serta berperan sebagai agen perubahan dalam pelayanan yang aktif terhadap transformasi masyarakat.

$$
\text { Pendidikan }
$$


Terkait hal tersebut, kegiatan pengabdian masyarakat yang dilakukan mahasiswa UPH, menjadi sebuah hal yang sangat relevan dengan profil lulusan yang dicanangkan institusi pendidikan Kristen ini. Tujuan pengabdian masyarakat seperti yang tertuang di goal UPH adalah untuk membangun individu dan masyarakat, hal ini sejalan dengan konsep dari pengembangan atau pembangunan masyarakat dan pekerjaan sosial. Mc Ardle dikutip Hikmat $(2001,6)$ mengatakan

"Pemberdayaan adalah upaya untuk menciptakan dan meningkatkan partisipasi aktif masyarakat dalam setiap proses pengambilan keputusan" Sedangkan Nugraha (2009) dalam jurnalnya menuliskan bahwa arti dari pembangunan masyarakat adalah semua kegiatan yang dilakukan oleh masyarakat sebagai perwujudan dari pengenalan akan permasalahan dan kebutuhan bersama.

Jadi pengembangan masyarakat adalah serangkaian usaha yang ditujukan untuk menolong masyarakat mengembangkan diri mereka yang bertumpu pada sumber daya lokal yang dimilikinya. Dalam hal ini peran pendamping masyarakat dibutuhkan untuk memfasilitasi masyarakat menyadari sumber daya yang dimiliki baik berupa sumber daya manusia, sumber daya alam, serta sumber daya sosial (nilai nilai budaya dan sosial yang ada dalam masyarakat, misal budaya gotong royong). Selanjutnya secara bersama sama menyusun perencanaan program untuk mengatasi masalah yang ada dalam masyarakat. Di dalam sebuah komunitas, masyarakat difasilitasi untuk menganalisa kebutuhan, menyusun prioritas, yang ditindaklanjuti dengan perencanaan program yang tepat untuk menjawab kebutuhan mereka.

Institusi pendidikan dan mahasiswa adalah bagian dari masyarakat, untuk itu mempunyai kewajiban melakukan tridarma perguruan tinggi , dalam hal ini adalah kegiatan pengabdian masyarakat. Kebersamaan dan keterlibatan semua orang termasuk mahasiswa, merupakan langkah yang tepat untuk pendekatan pengembangan masyarakat.

Menyikapi hal tersebut, salah satu kegiatan pengabdian yang dilakukan adalah layanan belajar yang diberikan kepada anak anak berkebutuhan khusus di salah satu gereja di Serpong Tangerang. Gereja ini mengadakan persekutuan untuk orang tua yang memiliki anak-anak yang berkebutuhan khusus. Tujuan dari persekutuan ini adalah untuk mendukung orangtua dari anak-anak yang berkebutuhan khusus, supaya tetap bersemangat dan mempunyai pengharapan dalam mengasuh dan membesarkan anak anak spesialnya. Ketika orangtua beribadah, anak- anak spesial ini juga perlu diberikan ibadah serta layanan belajar untuk mereka sendiri. Tetapi masalahnya mengajar dan menangani anak anak berkebutuhan khusus, memerlukan pendidikan khusus untuk memahami keberbedaan dari setiap jenis kebutuhan khusus dan juga bagaimana mengembangkan strategi yang tepat untuk menanganinya.

Istilah berkebutuhan khusus atau mengidap kelainan, menurut Effendi (2006) dalam konteks kehidupan sehari-hari seringkali diartikan sebagai keadaan yang menyimpang atau berbeda dari yang umumnya. Penyimpangan ini bisa memiliki nilai lebih atau sebaliknya ,kurang. Sehingga efek keberbedaan yang dialami seseorang seringkali menyita perhatian orang di sekelilngnya, baik hanya seketika saja atau berkepanjangan.Tulisan dari Brummelen (2015) menyatakan bahwa" murid berkebutuhan khusus adalah mereka yang memerlukan bantuan khusus agar dapat belajar dengan baik. Kebutuhan khusus yang paling umum dari urutan yang paling umum adalah ketidakmampuan belajar, kelainan perilaku, autisme dan cacat fisik. "Kekhususan inilah yang membuat mereka memerlukan strategi pembelajaran maupun strategi perlaku yang perlu dibedakan secara signifikan dari mayoritas murid yang lain. Abdullah (2013) dalam artikelnya berjudul Mengenal Anak Berkebutuhan khusus, mendefinisikannya sebagai anak yang secara jasmani, perilaku sosial maupun psikologisnya berbeda dari mayoritas anak anak normal lainnya. Oleh karenanya, berbagai masalah akan timbul terkait dengan kekhusannya tersebut. Selain pendidikan khusus, Dukes dan Smith (2009) mengingatkan perlunya beberapa aspek pribadi yang harus dipunyai oleh seorang pengajar, guna memenuhi kebutuhan khusus anak, serta meletakkan pondasi yang kokoh untuk bekerja sama dengan orangtuanya. Mengapa harus bekerja sama dengan orangtua? Dijelaskan bahwa bagi para orang tua yang mempunyai anak berkebutuhan khusus, bukanlah suatu hal yang mudah. Mereka akan berusaha sepenuh tenaga, daya dan pikirannya untuk memikirkan cara terbaik untuk

$$
\text { Pendidikan } \quad 856
$$


memenuhi kebutuhan anak-anaknya. Sehingga para pengajar harus benar benar bisa memanfaatkan pengetahuan yang dimiliki orang tua, dan memahami bahwa bagi mereka, meninggalkan anak-anak nya yang rentan di sekolah, adalah merupakan langkah berat dan sangat tidak mudah. Para pengajar harus mendapatkan kepercayaan dari para orang tua, dan bahwa mereka yakin bahwa orang tua akan mendapatkan akses untuk terlibat dalam kemajuan dan perkembangan anak di masa sekolah anak-anak tersebut. Aspek aspek tersebut adalah antara lain adalah 1) empati; 2) sikap menghormati dan tidak menghakimi keluarga; 3) kemampuan menyimak serta 4) kemampuan berbahasa tubuh yang baik. Empati dalam hal ini adalah memperlihatkan pemahaman dan kepedulian kepada anak-anak bekebutuhan khusus serta orangtuanya. Empati bertumbuh ketika pengajar memahami perasaan dan pengalaman anak beserta orang tua nya. Perasaan orang tua yang memiliki anak berkebutuhan khusus sangat beragam, dan bisa dibagi dalam dua tahapan. Tahap pertama biasanya dimulai dari kaget, menyangkal, sedih atau marah, merasa bersalah dan takut serta cemas. Lalu tahapan selanjutnya, orangtua sudah mulai bisa menerima dan menyesuaikan dengan kenyataan, berpikir positif dan praktis, sampai kemudian memikirkan semua hal yang terbaik untuk anak dalam keterbatasan kondisinya, termasuk pendidikannya. Selanjutnya adalah sikap menghormati dan tidak menghakimi. Tidak menghakimi berarti bersikap positif tentang orangtua, bahwa mereka adalah orang paling punya kepentingan untuk melakukan yang terbaik untuk anak-anak nya. Ketika pengajar mempunyai sikap positif seperti ini, maka hubungan baik akan terjalin dan tentu saja yang paling diuntungkan adalah anak-anak berkebutuhan khusus yang memang berhak untuk mendaptkannya. Aspek berikutnya adalah kemampuan menyimak. Menyimak adalah dengan seksama mendengarkan yang sedang disampaikan dan juga cara penyampaiannya. Aspek tersebut apabila dilakukan dengan baik, maka akan mencegah terjadinya kesalahpahaman penyampaian pesan.Untuk bisa menyimak dengan baik, diperlukan empati untuk memahami perasaan dan emosi orangtua. Memahami bukanlah selalu sependapat, tetapi bersedia mendiskusikan dan memaklumi perasaan orang tua. Terakhir adalah aspek bahasa tubuh, seringkali bahasa tubuh kita lakukan tanpa kita sadari. Sayangnya, hal tersebut mengirimkan pesan yang lebih kuat dari pada kata kata kita.

Hal lain yang perlu disoroti dari penyelenggaran pendidikan untuk anak berkebutuhan khusus adalah pada kenyataannya masih banyak anak-anak yang terlahir dalam kondisi seperti tersebut di atas, rentan untuk mendapatkan hak-hak nya, terkhusus hak untuk mendapatkan pendidikan. Seperti dikutip dari Mareza (2016) dalam jurnalnya menuliskan bahwa setiap manusia mempunyai hak asasi yang paling fundamental, yaitu pendidikan. Hal ini berlaku juga bagi anak anak berkebutuhan khusus. Undang-undang No. 20 Tahun 2003 tentang Sistem Pendidikan Nasional Pasal 32 disebutkan bahwa: "Pendidikan khusus (pendidikan luar biasa) merupakan pendidikan bagi peserta didik yang memiliki tingkat kesulitan dalam mengikuti proses pembelajaran karena kelainan fisik, emosional, mental, dan sosial, dan ataumemiliki potensi kecerdasan dan bakat istimewa

Dari penjelasan dan penjabaran di atas, dapat disimpulkan bahwa anak berkebutuhan khusus memerlukan penanganan khusus, dimana orang yang menanganinya pun harus memiliki pendidikan dan pengetahuan khusus tentang hal tersebut. Mahasiwa Fakultas Pendidikan UPH, mendapatkan mata kuliah Pendidikan Luar Biasa yang mempersiapkan mereka untuk dapat mengajar di sekolah inklusi.

Pendidikan inklusi menurut Direktorat PSLB dikutip dalam Tarnoto (2016) adalah sebuah sistem fasilitas pendidikan dimana anak anak berkebutuhan khusus ditempatkan di dalam kelas yang sama dengan anak-anak yang normal, di sekolah reguler yang paling dekat dengan rumahnya. Oleh sebab itu, sekolah diwajibkan untuk melakukan penyelarasan dari berbagai bidang, mulai dari pengembangan kurikulum, stategi pembelajaran, maupun prasarana dan sarana pendidikan, sehingga bisa mengakomodasi semua kebutuhan peserta didik.

Lokasi yang menjadi tempat pengabdian masyarakat UPH ini adalah sebuah gereja di Serpong Tangerang. Barawal dari banyak pengurus dan jemaat dari gereja tersebut yang mempunyai anak-anak berkebutuhan khusus, maka sebuah komunitas di gereja tersebut mengadakan persekutuan yang dikhususkan untuk orang tua yang mempunyai anak anak spesial. Komunitas ini menyadari bahwa memiliki anak berkebutuhan khusus merupakan sebuah tantangan bagi para orang tua. Kelelahan yang tidak hanya dilewati dalam waktu berjam-jam, bahkan bulan hingga tahun akan membuat orang tua merasa tidak memiliki

$$
\text { Pendidikan }
$$


harapan. Hal inilah yang menggerakkan komunitas di gereja tersebut untuk mengadakan persekutuan orang tua anak bekebutuhan khusus. Persekutuan ini memiliki tujuan untuk mendukung para orang tua untuk terus berpegang teguh pada Firman Tuhan dan terus mempunyai pengharapan. Persekutuan diadakan pada setiap hari Sabtu pada setiap bulannya. Orang tua yang mengikuti persekutuan tersebut memiliki anak-anak berkebutuhan khusus, yang terdiri dari anak autis ringan hingga sedang, tuna grahita (down syndrome), tuna daksa dan juga ADHD ( attention deficit hyperactive syndrome) atau biasa disebut anak hiperaktif dengan rentang perhatian yang pendek. Adapun penjelasan atau deskripsi dari masing masing gangguan atau kekhususan tersebut adalah sebagai berikut:

Pamoedji (2010) menuliskan bahwa autisme adalah development disorder yang sangat pelik pada anak. Dengan simptom yang muncul sebelum anak mencapai usia 3 tahun. Dimana gangguan ini akan mempengaruhi 3 kemampuannya, yaitu kemampuan berkomunikasi (berbicara dan bahasa), berinteraksi sosial (tidak tertarik berinteraksi), demikian juga perilakunya (hidup dalam dunianya sendiri). Pada umumnya, anak anak autis sebelum berusia 3 tahun sudah menunjukkan ketidaknormalan atau keterlambatan perkembangan dalam berinteraksi sosial, berbicara, dan bermain menggunakan daya imajinasi.

Tuna grahita (down syndrome) atau di dalam masyarakat sering dikenal dengan istilah keterbelakangan mental, adalah merupakan suatu kondisi seseorang memiliki IO atau kemampuan intelektual di bawah rata rata pada umumnya. Rendahnya IQ atau kemampuan kognitif ini mempengauhi cara berpikir dan kemampuan adaptif dari seorang anak tunagrahita. Dengan kata lain, anak tunagrahita memiliki keterbatasan dalam berikir abstrak, membuat keputusan, mengingat dan untuk memahami konsep sebab akibat. Tunagrahita menurut Pratiwi dan Hartosujono (2014), menurunnya kemampuan melakukan aktivitas gerakan tubuh tertentu yang disebabkan oleh penyakit, cedera maupun pertumbuhan yang salah perlakuan, sehingga fungsi anggota tubuhnya tidak optimal.
Selanjutnya Zaviera (2009:11) berpendapat bahwa “ anak hiperaktif adalah anak yang mengalami gangguan pemusatan perhatian dengan hiperaktifitas $(\mathrm{GPPH})$ atau attention deficit hyperactive syndrome $(A D H D)$...Gangguan hiperkinetik adalah gangguan pada anak yang timbul pada masa perkembangan dini (sebelum usia 7 tahun), dengan ciri utama tidak mampu memusatkan perhatian, hiperaktif, dan impulsif. Ciri perilaku ini mewarnai berbagai situasi dan dapat berlanjut hingga dewasa."

Dari penjabaran penjelasan di atas, dapat digambarkan bahwa kelas layanan belajar yang diadakan di gereja tersebut, akan dihadiri oleh berbagai macam anak-anak spesial yang mempunya disorderl gangguan perkembangan yang berbeda-beda. Sehingga sangat dimengerti akan kebutuhan pendamping / guru yang mengerti akan macam macam kebutuhan ini. Jumlah anak-anak spesial yang dilayani di gereja ini sejumlah 25 orang. Sedangkan jumlah mahasiswa yang tergabung dalam layanan pengabdian masyarakat ini adalah 15 orang, dengan 3 dosen pembimbing. Layanan yang dilaporkan dalam makalah ini, dimulai pada bulan Januari 2019 sampai dengan Mei 2019.

Pelayanan ini merupakan lanjutan dari program layanan tahun sebelumnya, dengan beberapa perbaikan diantaranya pembuatan tema per-minggu yang mengacu pada tema besar yaitu "Keluarga yang saling mengasihi". Selain anak-anak spesial, saudara kandung mereka yang tidak berkebutuhan khusus turut serta pada kegiatan layanan belajar ini.

Adapun tujuan dari layanan belajar ini adalah untuk 1) mendukung orangtua dari anak anak yang berkebutuhan khusus, supaya tetap bersemangat dan mempunyai pengharapan dalam mengasuh dan membesarkan anak anak spesialnya, dengan mengikuti kebaktian khusus untuk orangtua anak anak spesial di gereja di Serpong 2) menyediakan layanan belajar bagi anak-anak berkebutuhan khusus .

\section{METODE}

\section{Waktu dan Lokasi Kegiatan}

Kegiatan dilakukan di salah satu gereja di Serpong Tangerang. Waktu kegiatan dilaksanakan tiap semester, dan untuk tahun 2019 dilakukan pada bulan Januari sampai dengan Mei 2019.

$$
\text { Pendidikan }
$$




\section{Tahapan Pelaksanaan Kegiatan}

Manajemen pelaksanaan kegiatan adalah sebagai berikut 1) Pengajuan proposal ke LPPM; 2) MOU dengan pihak gereja; 3) Pelaksanaan; 4) Evaluasi.

Sedangkan metoda yang dipakai adalah berupa pengajaran Firman Tuhan dan pemberian aktivitas belajar bagi anak-anak baik yang berkebutuhan khusus maupun saudara-saudara kandung mereka. Para mahasiswa akan didampingi oleh mentor dari komunitas gereja, dan 3 dosen Teachers College. Skema pelaksanaan kegiatan secara umum adalah 1) ice breaking; 2) doa pembuka; 3) menyanyikan lagu pujian; 4) firman Tuhan; 5) kegiatan belajar bersama; 6) doa penutup.

\section{HASIL DAN PEMBAHASAN}

\section{Pelaksanaan}

Layanan belajar dilakukan selama 6 kali dari bulan Januari sampai Mei 2019. Dilakukan oleh sebanyak 15 mahasiswa dan 3 dosen pembimbing. Jumlah anak berkebutuhan khusus ada 25 anak dengan jenis kebutuhan khusus antara lain autism ringan hingga sedang, tuna grahita (down syndrome), tuna daksa dan juga ADHD (attention deficit hyperactive syndrome).

Pelaksanaan kegiatan tiap bulannya dapat dilihat dari bagan berikut :

\begin{tabular}{|c|c|c|}
\hline \multicolumn{3}{|c|}{ Sabtu, 5 Januari 2019} \\
\hline WAKT U & DURASI & KE GIAT AN ANAK \\
\hline $16.30-17.00$ & $30^{\circ}$ & Regis trasi \\
\hline $17.00-17.10$ & $10^{\circ}$ & Ice brealing \\
\hline $17.10-17.15$ & $5^{\prime}$ & Das Pembula \\
\hline $17.15-17.30$ & 15 & Menyanyikan lagu Pujian \\
\hline $17.30-17.50$ & $20^{\circ}$ & Penyampaian Fiman Tuhan \\
\hline $17.50-18.15$ & $25^{3}$ & Membvat Magnet Kulkas Salib\&hati \\
\hline $18.15-18.30$ & 15 & Sharing dan Daa Penutup \\
\hline
\end{tabular}

Sabtu, 12 Januari 2019

\begin{tabular}{rll} 
WAKT U & DURASI & \multicolumn{1}{c}{ KE GAT AN ANAK } \\
$16.30-17.00$ & $30^{\circ}$ & Registrasi \\
$17.00-17.20$ & $20^{\circ}$ & Pujian Penyembahan \\
$17.20-17.40$ & $20^{\circ}$ & Penyampaian Fiman Tuhan \\
\hline $17.40-18.00$ & $20^{\circ}$ & Belajar Membuat Gantungan Pintu \\
\hline $18.00-18.15$ & $15^{\circ}$ & Sharing dan Doa Penutup \\
\hline
\end{tabular}

Sabtu, 9 F ebruari 2019

\begin{tabular}{c|l|l|}
\hline WAKTU & DURASI & KEGLATAN ANAK \\
$16.30-17.00$ & $30^{\circ}$ & Registrasi \\
$17.00-17.20$ & $20^{\circ}$ & Pujian Penyembahan \\
$17.20-17.40$ & $20^{\circ}$ & Penyampaian Firman Tuhan \\
\hline $17.40-18.00$ & $20^{\circ}$ & Belajar Membuat Bunga dari Origami \\
$18.00-18.15$ & $15^{\prime}$ & Sharing dan Doa Penutup
\end{tabular}

Sabtu, 2 Mare 2019

\begin{tabular}{|c|c|c|}
\hline $\begin{array}{l}\text { WAKT U } \\
16.30-17.00 \\
\end{array}$ & $\begin{array}{l}\text { DURASI } \\
30^{\circ}\end{array}$ & KE GIAT AN ANAK \\
\hline $17.00-17.20$ & $20^{\circ}$ & Pujian Penyembahan \\
\hline $17.20-17.40$ & $20^{\circ}$ & Penyampaian Firman Tuhan \\
\hline $17.40-18.00$ & $20^{\circ}$ & Belajar Membuat G antung an Pintu \\
\hline $18.00-18.15$ & $15^{\prime}$ & Sharing dan Doa Penvtup \\
\hline
\end{tabular}

Sabtu, 6 April2019

\begin{tabular}{lll} 
WAKT U & DURASI & \multicolumn{1}{c}{ KE GAT AN ANAK } \\
\hline $16.30-17.00$ & $30^{\circ}$ & Registrasi \\
\hline $17.00-17.20$ & $20^{\circ}$ & Pujian Penyembahan \\
\hline $17.20-17.40$ & $20^{\circ}$ & Peryampaian Fiman Tuhan \\
\hline $17.40-18.00$ & $20^{\circ}$ & Belajar konsentrasi lew at permainan \\
$18.00-18.15$ & $15^{\prime}$ & Sharing dan Doa Penutup
\end{tabular}

Sabtu, 4 Mei 2019

\begin{tabular}{lll}
$\begin{array}{c}\text { WAKT U } \\
16.30-17.00\end{array}$ & $\begin{array}{c}\text { DURASI } \\
30^{\circ}\end{array}$ & Registrasi \\
\hline $17.00-17.20$ & $20^{\circ}$ & Prjian Penyembahan \\
\hline $17.20-17.40$ & $20^{\circ}$ & Penyampaian Fiman Tuhan \\
\hline $17.40-18.00$ & $20^{\circ}$ & Belajar Membuat Magnet Ku 1has + Hati \\
\hline $18.00-18.15$ & $15^{\prime}$ & Sharing dan Daa Penutup
\end{tabular}

Sementara anak-anak berkebutuhan khusus dan saudaranya melakukan kegiatan kebaktian dan aktifitas belajar, para orangtuanya di ruangan lain melakukan kegiatan ibadah dengan urutan kegiatan sebagai berikut : 1) Menyanyikan lagu pujian; 2) Kesaksian dari orang tua; 3) Penyampaian Firman Tuhan 4) Penutup; 5) Sharing dan ramah tamah.

Kegiatan pengabdian masyarakat berupa penyediaan layanan belajar bagi anak-anak berkebutuhan khusus yang dilakukan mahasiswa guru UPH bekerjasama dengan sebuah komunitas gereja di Serpong ini mendapatkan sambutan yang sangat baik dari para orang tua anak-anak ini. Mereka menyatakan bahwa dengan adanya kegiatan layanan belajar ini

$$
\text { Pendidikan }
$$


membantu orang tua untuk dapat beribadah dengan leluasa dan mendapatkan penguatan secara moral maupun spiritual. Jumlah anak-anak berkebutuhan khusus dan orangtuanya yang mengikuti kegiatan ini meningkat dibanding tahun lalu, yang juga merupakan bukti dari tanggapan positif terhadap kegiatan pengabdian masyarakat mahasiswa guru UPH di gereja ini.

Di samping itu, berdasarkan observasi yang dilakukan oleh dosen bersama dengan mahasiswa didapatkan hasil antara lain adalah 1) layanan belajar ini menjadi tempat untuk mengembangkan kemampuan sosial anak-anak tuna daksa yang terlibat kegiatan ini. Seperti yang dinyatakan oleh Effendi (2006:131) tentang penyesuaian sosial anak tunadaksa :

"Ragam karakteristik ketunadaksaan yang dialami oleh seseorang menyebabkan tumbuhnya berbagai kondisi kepribadian dan emosi. Meskipun demikian, kelainan kepribadian dan emosi tidak secara langsung diakibatkan oleh ketunaanya, melainkan ditentukan oleh bagaimana seseorang itu berinteraksi dengan lingkungannya. “

Lebih lanjut lagi dinyatakan hal hal negatif yang kadang kala tidak terhindarkan terjadi pada anakanak dengan kekhusus-an tuna daksa ini. Hal hal tersebut adalah anak tuna daksa merasa dibedakan dengan anak-anak lain yang tidak mengalami gangguan tersebut. Dalam hal ini, mahasiswa guru UPH telah dididik untuk tidak membedakan anakanak spesial ini, hanya karena keberbedaanya. Hal yang lain lagi yang mungkin muncul adalah perkembangan pribadi anak yang terhambat, yang disebabkan karena kekhawatiran dan proteksi yang berlebihan terhadap anak nya. Di dalam kegiatan layanan belajar ini, orang tua pun belajar untuk mempercayakan anak-anaknya kepada para mahasiswa guru yang melakukan kegiatan pengabdian ini. Dan hasilnya pun, orang tua merasa senang dan sangat terbantu. Dari sisi perilaku, anakanak tunadaksa ini seringkali merasa frustasi karena tidak bisa beraktifitas dengan bebas seperti anakanak normal lainnya. Hal ini seringkali muncul dalam bentuk ketidaksabaran dan berteriak atau melempar benda benda yang digunakan untuk aktifitas belajar. Peran mahasiswa guru di sini sangat penting, di dalam memahami kekesalan dan fustasi yang dirasakan anak-anak ini. Mereka akan mendampingi dan menolong setiap tahapan kegiatan layanan belajar yang diberikan.

Effendi lebih lanjut lagi menjelaskan mengenai gejala keterlambatan anak tuna grahita dalam hal perkembangan sosial disebabkan oleh beberapa hal seperti, anak tuna grahita tidak atau kurang diberikan kesempatan untuk bersosialisasi, sehingga mengakibatkan anak tidak punya motivasi dan juga tidak ada bimbingan bagaimana melakukan hubungan atau interaksi sosial (Effendi 2006:103). Kondisi ini bisa disebabkan karena orang tua atau pengasuh anak tuna grahita malu dan merasa bersalah akan kondisi anak nya, sehingga takut akan mendapat cemooh dari masyarakat sekitar apabila anak nya yang mempunyai kebutuhan khusus ini bersosialisasi dengan banyak orang. Kegiatan layanan belajar ini menjadi wadah bagi anak-anak tuna grahita ini untuk mengembangkan kemampuan sosialnya dengan teman teman sebayanya ataupun dengan guru guru pembimbing dari UPH maupun dari komunitas gereja. Sementara orang tua pun menemukan komunitasnya sesama orang tua yang mempunyai anak anak berkebutuhan khusus, sehingga tidak perlu khawatir dicemooh maupun dihakimi. Malahan orang tua mendapatkan teman teman baru yang saling mendukung dan menguatkan baik secara moral maupun spiritual.

Berikutnya untuk anak-anak dengan gangguan autism Tung (2015:134) berpandangan bahwa salah satu prosedur untuk menangani untuk anak autis adalah dengan terapi komunikasi. Terapi komunikasi dilakukan untuk membantu anak mengembangkan kemampuannya untuk berkomunikasi. Pada saat kegiatan belajar dilakukan, anak-anak yang terlibat dalam program ini, dikondisikan untuk melatih ketrampilan komunikasi mereka, dimulai dari menyanyikan lagu lagu pujian, penyampaian firman Tuhan dalam bentuk cerita, aktifitas yang melatih motorik kasar maupun halus, dan ditutup dengan doa.

Selanjutnya untuk anak-anak $A D H D$, Santrock $(2009 ; 250)$ berpandangan bahwa ciri khas anak-anak

$$
\text { Pendidikan } \quad 860
$$


ini adalah rentang perhatiannya pendek sehingga tidak dapat atau susah untuk berkonsentrasi dalam jangka waktu yang lama. Ia akan mengalami kesulitan dalam mengarahkan fokus perhatiannya pada pelajaran maupun instruksi yang diberikan guru. Ia selanjutnya juga menyatakan strategi untuk menghadapi anak-anak ini, diantaranya adalah memakai instruksi yang sederhana ketika memberikan tugas, tidak hanya menggunakan petunjuk verbal melainkan juga memperkaya dengan instruksi visual (misal menggunakan gambar, kartu ataupun poster). Strategi ini diadaptasi didalam kegiatan layanan belajar yang diadakan di gereja ini.

Dari hasil observasi dosen dan para mahasiswa, dilakukan pula evaluasi untuk perbaikan kegiatan di semester berikutnya. Beberapa evaluasi tersebut adalah 1) Pengajuan usulan untuk mahasiswa guru terllibat di dalam pembuatan perencanaan program, dimana hal ini sesuai dengan konsep pemberdayaan masyarakat yang sudah dijabarkan di bagian pendahuluan. 2) Pengembangan data base data diri anak-anak berkebutuhan khusus dan saudaranya yang ikut dalam program ini

\section{KESIMPULAN}

Kegiatan pengabdian masyarakat berupa penyediaan layanan belajar bagi anak-anak berkebutuhan khusus yang dilakukan mahasiswa guru UPH bekerjasama dengan sebuah komunitas gereja di Serpong ini mendapatkan sambutan yang sangat baik dari para orang tua, dan menjawab kebutuhan orangtua untuk dapat beribadah dan anak anaknya mendapatkan layanan belajar.

Program layanan belajar ini perlu dilanjutkan pada semester berikutnya dengan mempertimbangkan dari beberapa evaluasi yang sudah disampaikan.

Sejalan dengan keberlajutan program, maka akan diadakan pembaharuan perjanjian MoU untuk periode Agustus-Desember 2019.

\section{REFERENSI}

Abdullah, Nadia. (2013) Mengenal Anak Berkebutuhan Khusus . Jurnal Magistra No. 86 Th. XXV Desember 2013 Psikologi Fakultas Psikologi UNWIDHA Klaten

Dukes C. \& Smith M. (2009) Cara Menangani Anak Berkebutuhan. PT Indeks Jakarta

Brummelen,H (2015) Berjalan Bersama Tuhan Di Dalam Kelas (edisi ketiga ACSI Jakarta

Effendi, M (2006) Pengantar Psikopedagogik Anak Berkelainan (edisi pertama) PT Bumi Akhsara Jakarta

Mareza,Lia (2016) Pengajaran Kreativitas Anak Berkebutuhan Khusus Pada Pendidikan Inklusi.Jurnal Indigenous Vol 1 No 2, 2106. FKIP Universitas Muhamadiyah Purwokerto

Pamoedji,G (2010) Pertanyaan dan Jawaban Seputar Autisme (cetakan pertama) Penerbit Hasanah Jakarta

Pratiwi, I \& Hartosujono (2014) Resiliensi Pada Penyandang Tuna Daksa Non Bawaan Jurnal SPIRITS, Vol.5, No.1, 2014. Fakultas Psikologi Universitas Sarjanawiyata Tamansiwa Yoyakarta

Santrock,J (2009) Psikologi Pendidikan (edisi ketiga)

Penerbit Salemba Humanika Jakarta

Tarnoto, Nisa (2016) Permasalahan-Permasalahan Yang Dihadapi Sekolah Penyelenggara Pendidikan Inklusi Pada Tingkat SD. Jurnal HUMANITAS Vol. 13 No.1, 2016 Fakultas Psikologi, Universitas Ahmad Dahlan Yogyakarta

Tung, K (2015) Pembelajaran dan Perkembangan Belajar. Penerbit Indeks Jakarta

Visi Misi UPH http://www.ac.id/id

Zaviera, F( 2009) Anak Hiperaktif Cara Cerdas Menghadapi Anak Hiperaktif dan Gangguan Konsentrasi (edisi kedua) Yogyakarta, Kata Hati 

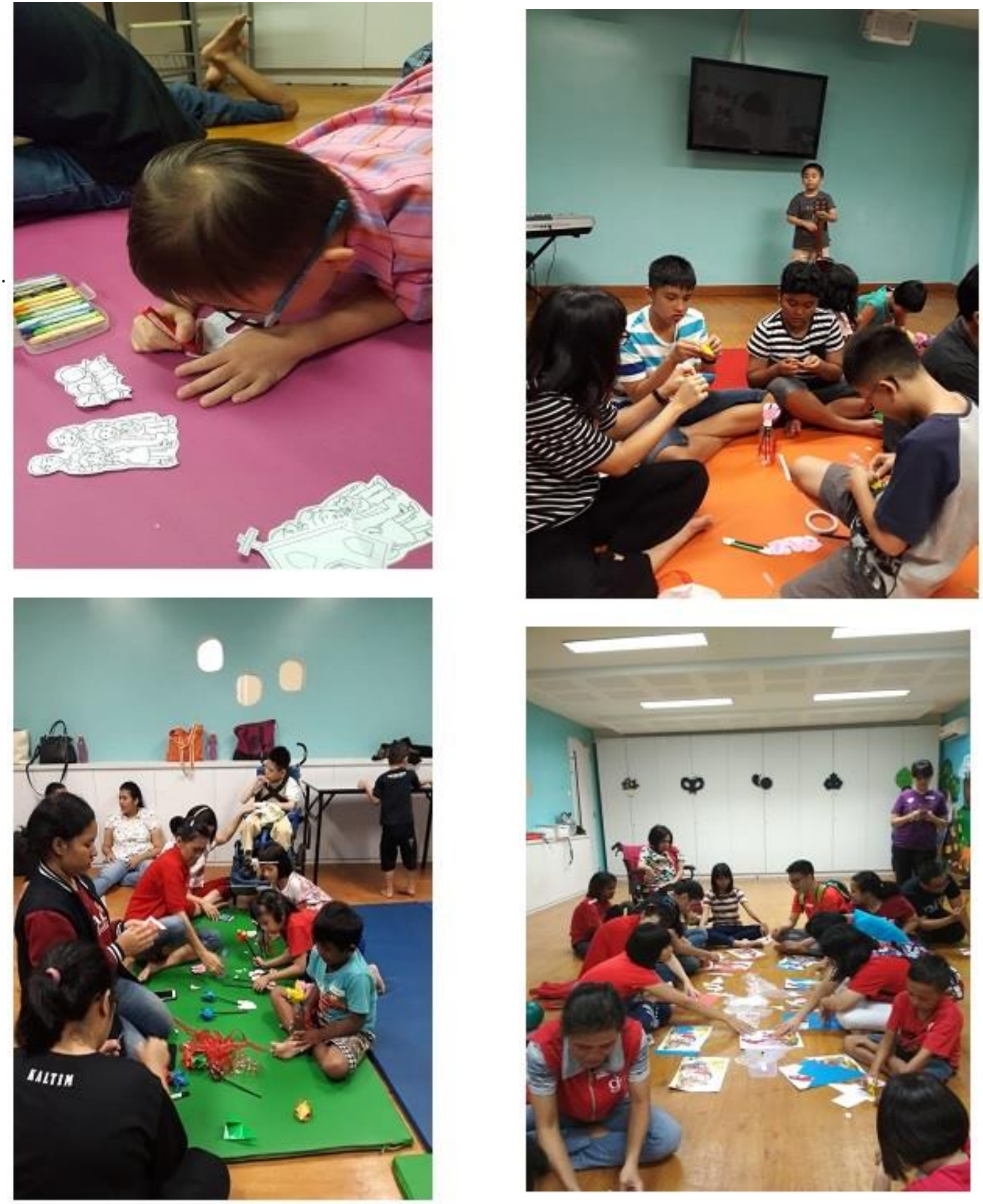